American Political Science Association
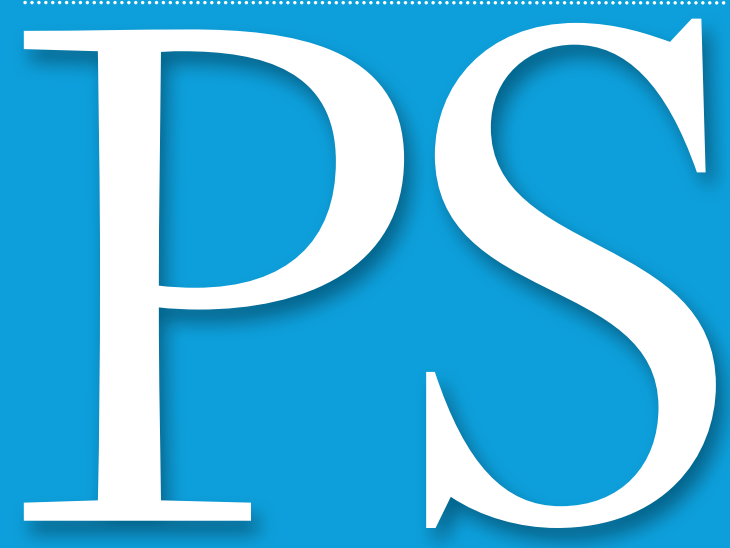

Political Science \& Politics

A P R I L 2015 , VOL U M 48 , N U M B E 2
Reinventing The Scholarly Conference:

Reflections from the Field

Mark Carl Rom, guest editor

Paul Pierson's Dismantling the Welfare State:

A 2oth Anniversary Reassessment

Eric M. Patashnik, guest editor

Evaluations of the 2014 Midterm Election Forecasts

James E. Campbell, guest editor

The Logic of the Promotion Decision:

In Dubio Pro Patientia

Kurt Weyland

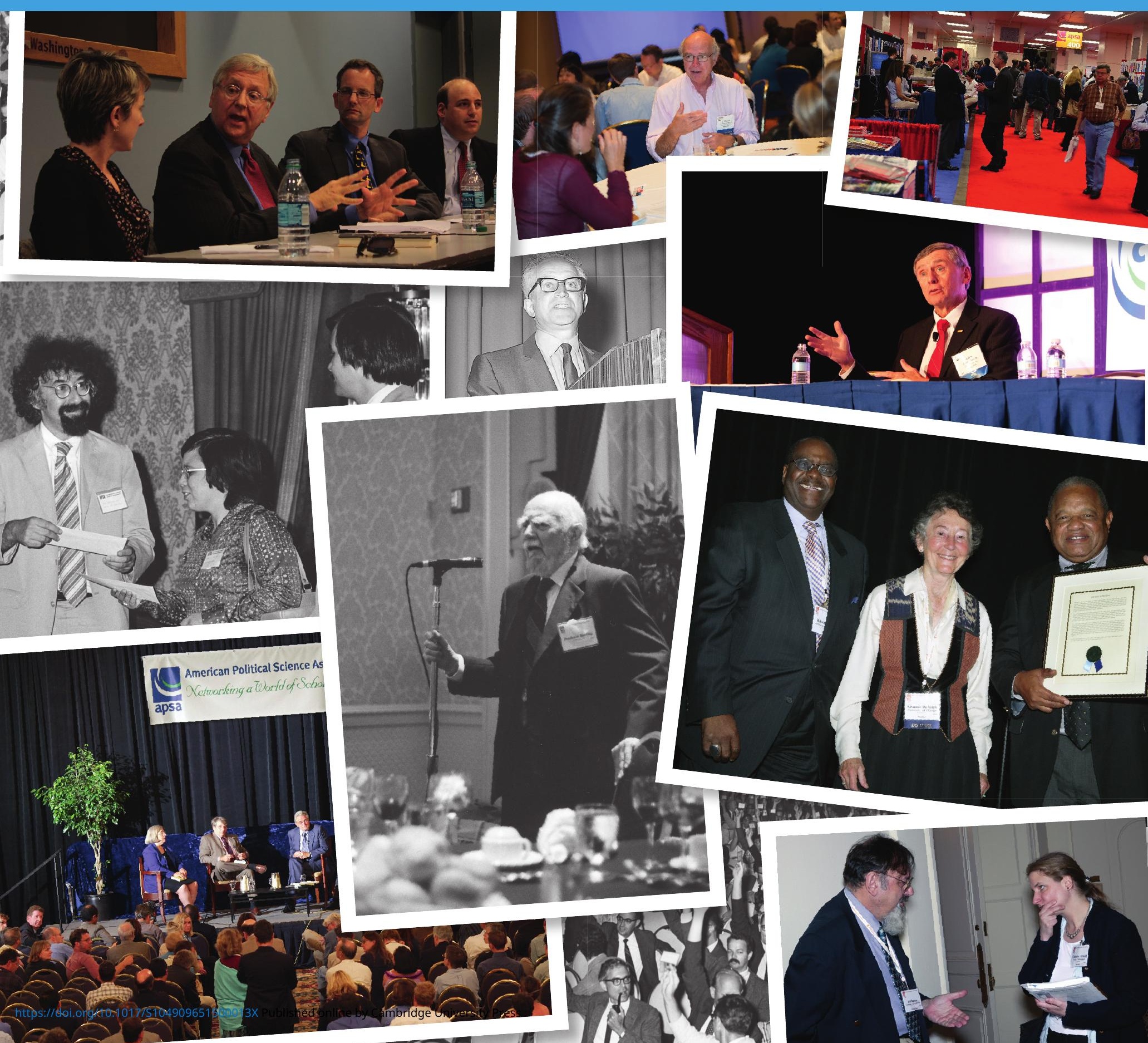




\section{$111^{\text {th }}$ APSA ANNUAL MEETING SEPTEMBER 3-6, 2015 | SAN FRANCISCO, CA}

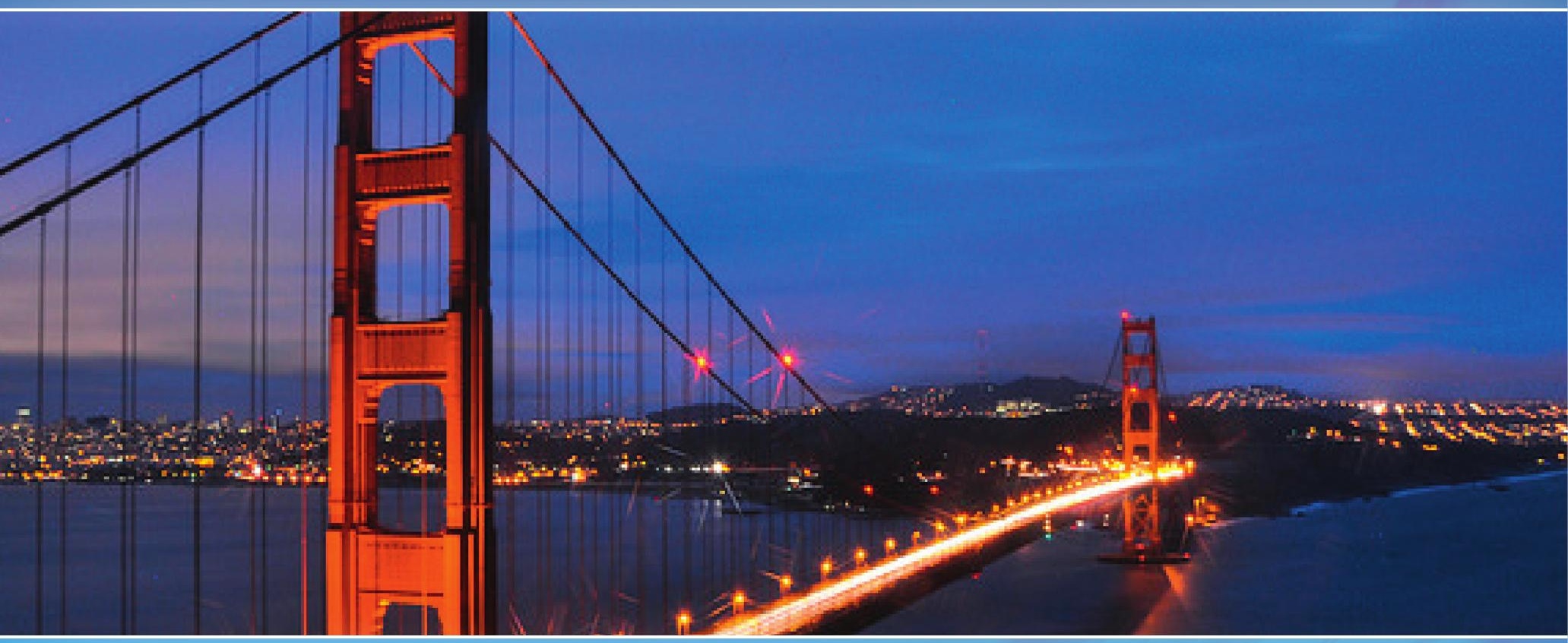

\section{REGISTRATION OPENS IN MARCH!}

Engage with 6,500 of your colleagues and address the latest scholarship in political science while exploring this year's theme:

Diversities Reconsidered: Politics $\&$ Political Science in the $21^{\text {st }}$ Century

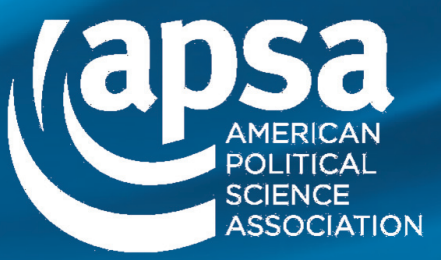




\section{symposıum Paul Pierson's Dismantling the Welfare State:}

\section{A Twentieth Anniversary Reassessment}

267 Introduction

Eric M. Patashnik, guest editor

270 Twenty Years On: Paul Pierson's Dismantling the Welfare State? Suzanne Mettler

274 Revisiting Pierson's Work on the Politics of Welfare State Reform in the Era of Retrenchment Twenty Years Later John D. Stephens

279 Still Not Dismantling? The Legacy of Dismantling the Welfare State in Comparative Politics Jane Gingrich

284 The Durability of Pierson's Theory about the Durability of the Welfare State Andrea Louise Campbell

289 Social Policy-Making for the Long Term Peter A. Hall

292 Reflections on the Evolution of a Research Program Paul Pierson

SYMPOSIUM

FEATURES

\section{Evaluations of the 2014 Midterm Election Forecasts} James E. Campbell, guest editor

296 The Generic Ballot Model and the 2014 Congressional Elections Alan I. Abramowitz

296 Forecasting the 2014 House Seat Division in Retrospect Joseph Bafumi, Robert S. Erikson, and Christopher Wlezien

297 Catching the 2014 Republican Wave James E. Campbell

297 Forecasting Lessons from 2014: Long Lead, Strong Theory, No Polls Michael S. Lewis-Beck and Charles Tien

298 Election Lab Post-Mortem

Benjamin Highton, Eric McGhee, and John Sides

301 Strategic Voting and the Role of Polls: Evidence from an Embedded Web Survey Timothy S. Rich

306 The BDS Campaign against Israel: Lessons from South Africa Joseph E. Yi and Joe Phillips

PROFESSION SYMPOSIUM
Reinventing the Scholarly Conference: Reflections from the Field

Introduction,

Mark Carl Rom, guest editor

315 Reconsidering the Scholarly Conference for the Contemporary Academic Michelle D. Deardorff 
319 Professional Conferences and the Challenges of Studying Black Politics Nikol G. Alexander-Floyd, Byron D'Andra Orey, and Khalilah Brown-Dean

324 Conquering the "Lumbering Dinosaur": Graduate Student Experiences at Political Science Conferences Amanda Rutherford

328 Notes on the Romulan Reform of Conventions Kenneth J. Meier

332 Reinventing the Scholarly Conference: Videotape the Presentations, Flip the Panels Mark Carl Rom

337 Defending the Federation from the Rom-ulan Empire or, If Conferences Ain't Broke, Don't Fix Them

David L. Leal

THE PROFESSION

THE TEACHER

PEOPLE 385
The Logic of the Promotion Decision: In Dubio Pro Patientia Kurt Weyland

Peer Reviewing in Political Science: New Survey Results Paul A. Djupe

The Dictatorship Game: Simulating a Transition to Democracy Luis F. Jiménez

Teaching with SimCity: Using Sophisticated Gaming Simulations to Teach Concepts in Introductory American Government Matthew Woessner

Teaching Globalization and Development through a Simulation Kevin Pallister

Political Theory Simulations in the Classroom: Simulating John Locke's Second Treatise of Government Derek Glasgow

Social Science Mechanics: A Graduate Training Module that "Looks under the Hood" at Innovative Research Designs

Katie A. Cahill, Michael R. Brownstein, Amanda E. Burke, Christopher Kulesza, and James A. McCann

Turning Introductory Comparative Politics and Elections Courses into Social Science Research Communities Using Wikipedia: Improving Both Teaching and Research Ryan Kennedy, Eric Forbush, Brian Keegan, and David Lazer

Spotlights

$$
\text { Books by Our Readers }
$$

In Memoriam

111th APSA Annual Meeting \& Exhibition Announcement: Diversities Reconsidered 12th Annual APSA Teaching and Learning Conference Report of the Editor of American Political Science Review, 2013-2014 2015-2016 APSA Minority Fellows Announced 
402

RBSI and MFP Alumni Academic and Professional Updates

403

Congressional Fellowship Program: A Health Professional's Political Science Education: Lessons from a Congressional Fellowship

\section{Nadine Braunstein}

407 International

409 Gazette

\section{DEPARTMENTS}

$\begin{array}{ll}385 & \text { People } \\ 393 & \text { Association News } \\ 407 & \text { International } \\ 409 & \text { Gazette }\end{array}$

On the Cover

The cover displays a collage of APSA and other academic conferences and meetings from APSA archives. Design by Drew Meadows.

Clockwise from Bottom Left: 2004 100th APSA Annual Meeting plenary session with George Soros; Ira Katznelson with two other scholars at the 1979 annual meeting; Francis Lee, Thomas Mann, Matt Green, and David Karol at a 2012 NCAPSA roundtable; APSA Council Member J. Donald Moon interacting with new members at a 2014 breakfast; the 2004 APSA Annual Meeting exhibit hall; APSA President John Aldrich presenting the 2014 keynote address; 2004 APSA President Susanne Rudolph presenting a Goodnow award to Michael B. Preston, right; Ed Barnas of Cambridge University Press speaks to Christine Arnold, Vrije Universite, in 2004 after a roundtable on getting published. Middle Top: David Easton speaking at the 1969 Annual Meeting. Middle Bottom: Pendleton Herring speaking at a bygone APSA meeting.

Letters to the Editor Welcomed

Letters via mail or e-mail will be considered for publication in future issues. All submissions should include your name, postal address, daytime telephone number, and e-mail address. Letters will be edited for length and style.

Contact

PS: Political Science and Politics

American Political Science Association

1527 New Hampshire Avenue, NW

Washington, DC 20036-1206

E-mail: ps@apsanet.org

Website: www.apsanet.org/PS/.

Submissions

Guidelines for submitting articles are posted online at www.apsanet.org/PS/.

PS Reprint Permissions

Reprints of $P S$ articles for class use are available through the Academic Permissions Service of the Copyright Clearance Center, 2322 Rosewood Drive, Danvers, MA 01923; phone: (978) 750-8400; fax: (978) 750-4744; or online at www.copyright.com.
EDITORS: Phillip Ardoin, Appalachian State University Paul Gronke, Appalachian State University and Reed College

MANAGING EDITOR: Celina Szymanski

EDITORIAL ASSISTANTS: Drew Meadows Chelsey Meade

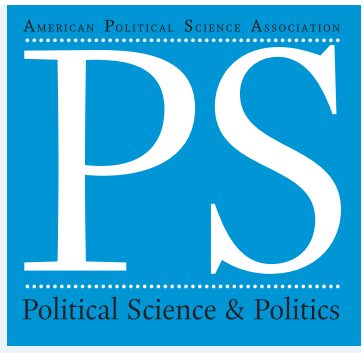

EDITORIAL BOARD:

Matthew R. Cleary, Syracuse University; Heath Fogg Davis, Temple University; Diana Evans, Trinity College; Rodolfo Espino III, Arizona State University; Jennifer Gandhi, Emory University; Matthew Hindman, Arizona State University; Liesbet Hooghe, University of North Carolina, Chapel Hill; Jennifer Jerit, Stony Brook, SUNY; Alisa Kessel, University of Puget Sound; Ari Kohen, University of Nebraska, Lincoln; Kathryn C. Lavelle, Case Western Reserve University; Lori Marso, Union College; Rose McDermott, Brown University; Ronald J. Schmidt, Sr., California State University, Long Beach; and Catherine Warrick, Villanova University.

\section{ASSOCIATION OFFICE ADDRESS AND MEMBERSHIP INFORMATION:}

American Political Science Association individual membership dues are: regular members with income \$200,00o+, \$320; \$135, ooo-199,999, \$271; \$100,000-134,000, \$241; \$80,000-99,999, \$207; \$6o,000-79,999, \$186; \$50,00o-59,999, \$170; \$40,000-49,999, \$145; under \$40,ooo, \$98; retired members $\$ 25,000+, \$ 66$; retired under $\$ 25,000, \$ 40$; targeted international member (TIM), \$40; life member, $\$ 3,000$; associate member, one journal, \$62; high school teacher (PS only), \$45; student member, \$45; unemployed member, $\$ 45$. The amount of the dues allocated for a subscription is $\$ 5.75$ for an individual membership.

Changes of address for members should be completed online or mailed to the APSA membership office at: APSA, 1527 New Hampshire Avenue, NW, Washington, DC 20036-1206.

\section{SUBSCRIPTION, PUBLISHING, AND ADVERTISING OFFICE ADDRESS:}

Cambridge University Press, 32 Avenue of the Americas, New York, NY 10013-2473; and (outside North America) Cambridge University Press, University Printing House, Shaftesbury Road, Cambridge CB2 8BS, England.

SUBSCRIPTION INFORMATION: PS: Political Science $\mathcal{E}$ Politics (ISSN 1049-0965) is published in January, April, July, and October by Cambridge University Press for the American Political Science Association. Annual institutional electronic-only subscription rate (2015) is US\$1119 in the United States, Canada, and Mexico, UK£625 elsewhere. Annual institutional printand-electronic subscription rate (2015) is US\$1297 in the United States, Canada, and Mexico, $U K £_{716}$ elsewhere. Periodicals postage rate paid at New York, NY, and additional mailing offices. POSTMASTER: Address changes should be sent to: PS: Political Science $\mathcal{E}$ Politics, Cambridge University Press, 100 Brook Hill Drive, West Nyack, NY 10994-2133, USA.

Copyright (C) 2015 by the American Political Science Association. All rights reserved. No part of this publication may be reproduced, in any form or by any means, electronic, photocopying, or otherwise, without permission in writing from Cambridge University Press. Photocopying information for users in the USA: The Item-Fee Code for the publication (1049-0965/15 $\$ 15.00+\$ .10)$ indicates that copying for internal or personal use beyond that permitted by Sec. 107 or 108 of the U.S. Copyright Law is authorized for users duly registered with the Copyright Clearance Center (CCC) Transaction Reporting Service, provided that the appropriate remittance of $\$ 15.00$ per article is paid directly to CCC, 222 Rosewood Drive, Danvers, MA 01923. Specific written permission must be obtained for all other copying. ADVERTISING: $P S$ has a circulation of 16,00o. Please contact our Advertising Sales Team at USAdSales@cambridge.org for full advertising information including rates and specs.

compositıon: TNQ Books and Journals Pvt. Ltd., Chennai, India. PRINTING AND DISTRIBUTION: Dartmouth Printing Co., Hanover, NH. 


\section{About APSA}

Founded in 1903, the American Political Science Association is theleading professional organization for the study of political science and serves more than 15,000 members in over 80 countries. With a range of programs and services for individuals, departments, and institutions, APSA brings together political scientists from all fields of inquiry, regions, and occupational endeavors within and outside academe in order to expand awareness and understanding of politics.

The direct advancement of knowledge is at the core of APSA activities. We promote scholarly communication in political science through a variety of initiatives including publishing three distinguished journals: American Political Science Review, Perspectives on Politics, and PS: Political Science and Politics.

\section{Officers}

\section{PRESIDENT}

Rodney E. Hero

University of California, Berkeley

\section{PRESIDENT-ELECT}

Jennifer Hochschild

Harvard University

\section{VICE-PRESIDENTS}

E. J. Dionne, Jr.

Georgetown University

Brookings Institution

Joanne Gowa

Princeton University

Fredrick C. Harris

Columbia University

\section{TREASURER}

Kathleen Thelen

Massachusetts Institute of Technology

\section{SECRETARY}

Linda L. Fowler

Dartmouth College

\section{PROGRAM CO-CHAIRS}

Layna Mosley

University of North Carolina,

Chapel Hill

Alvin Bernard Tillery

Northwestern University

\section{EDITOR-IN-CHIEF, APSR}

John Ishiyama

University of North Texas

\section{EDITOR-IN-CHIEF,} PERSPECTIVES

Jeffrey C. Isaac

Indiana University

\section{EXECUTIVE DIRECTOR}

Steven Rathgeb Smith

American Political Science Association

\section{Council}

\section{3-2015}

Amrita Basu

Amherst College

Kenneth R. Benoit

London School of Economics

Christine Di Stefano

University of Washington

James N. Druckman

Northwestern University

Hank C. Jenkins-Smith

University of Oklahoma

David C. Kang

Universtiy of Southern California

John M. Sides

George Washington University

Evelyn M. Simien

University of Connecticut

\section{4-2016}

Michelle D. Deardorff

University of Tennessee,

Chattanooga

Maria C. Escobar-Lemmon

Texas A \& M University

Frances E. Lee

University of Maryland, College

Park

David Lublin

American University

Marc Lynch

George Washington University

Tasha Philpot

University of Texas, Austin

David Stasavage

New York University

Mark E. Warren

University of British Columbia

Former APSA Presidents

Frank J. Goodnow

Albert Shaw

Frederick N. Judson

James Bryce

A. Lawrence Lowell

Woodrow Wilson

Simeon E. Baldwin

Albert Bushnell Hart

W. W. Willoughby

John Bassett Moore

Ernst Freund

Jesse Macy

Munroe Smith

Henry Jones Ford

Paul S. Reinsch

Leo S. Rowe

William A. Dunning

Harry A. Garfield

James W. Garner

Charles E. Merriam

Charles A. Beard

William Bennett Munro

Jesse S. Reeves

John A. Fairlie

Benjamin F. Shambaugh

Edward S. Corwin

William F. Willoughby

Isidor Loeb

Walter Shepard

Francis W. Coker

Arthur N. Holcombe

Thomas Reed Powell

Clarence A. Dykstra

Charles Grove Haines

Robert C. Brooks

Frederic A. Ogg

William Anderson

Robert E. Cushman

Leonard D. White

John Gaus

Walter F. Dodd

Arthur W. MacMahon

Henry R. Spencer

Quincy Wright

James K. Pollock

Peter H. Odegard

Luther Gulick

Pendleton Herring

Ralph J. Bunche

Charles McKinley

Harold D. Lasswell

E. E. Schattschneider

V. O. Key, Jr.

R. Taylor Cole

Carl B. Swisher
Emmette S. Redford Charles S. Hyneman

Carl J. Friedrich

C. Herman Pritchett

David B. Truman

Gabriel A. Almond

Robert A. Dahl

Merle Fainsod

David Easton

Karl W. Deutsch

Robert E. Lane

Heinz Eulau

Robert E. Ward

Avery Leiserson

Austin Ranney

James MacGregor Burns

Samuel H. Beer

John C. Wahlke

Leon D. Epstein

Warren E. Miller

Charles E. Lindblom

Seymour Martin Lipset

William H. Riker

Philip E. Converse

Richard F. Fenno

Aaron B. Wildavsky

Samuel P. Huntington

Kenneth N. Waltz

Lucian W. Pye

Judith N. Shklar

Theodore J. Lowi

James Q. Wilson

Lucius J. Barker

Charles O. Jones

Sidney Verba

Arend Lijphart

Elinor Ostrom

M. Kent Jennings

Matthew Holden, Jr.

Robert O. Keohane

Robert Jervis

Robert D. Putnam

Theda Skocpol

Susanne Hoeber Rudolph

Margaret Levi

Ira Katznelson

Robert Axelrod

Dianne M. Pinderhughes

Peter Katzenstein

Henry E. Brady

Carole Pateman

G. Bingham Powell, Jr.

Jane Mansbridge

John H. Aldrich 